\title{
Unity lost. Negotiating the ancient roots of Pedagogy in Sweden, 1865-1971
}

\author{
Isak Hammar \\ Department of History, Stockholm University, Stockholm, Sweden, and \\ Hampus Östh Gustafsson \\ Department of History of Science and Ideas, Uppsala University, Uppsala, Sweden
}

\begin{abstract}
Purpose - The purpose of this article is to investigate attempts to safeguard classical humanism in secondary schools by appealing to a cultural-historical link with Antiquity, voiced in the face of educational reforms in Sweden between 1865 and 1971.

Design/methodology/approach - By focusing on the content of the pedagogical journal Pedagogisk Tidskrift, the article highlights a number of examples of how an ancient historical lineage was evoked and how historical knowledge was mobilized and contested in various ways.

Findings - The article argues that the enduring negotiation over the educational need to maintain a strong link with the ancient past was strained due to increasing scholarly specialization and thus entangled in competing views on reform and what was deemed "traditional" or "modern".

Originality/value - From a larger perspective, the conflict over the role of Antiquity in Swedish secondary schools reveals a trajectory for the history of education as part of and later apart from a general history of the humanities. Classical history originally served as a common past from which Swedish culture and education developed, but later lost this integrating function within the burgeoning discipline of Pedagogy. The findings demonstrate the value of bringing the newly (re)formed history of humanities and history of education closer together.
\end{abstract}

Keywords Pedagogy, Classical humanism, History of humanities, Educational reform, Historical knowledge, Arena of knowledge

Paper type Research paper

\section{Introduction}

In 1905, following a series of attempts to include vocational and practical subjects in the curriculum for secondary schools, an educational reform finally dealt with what many perceived to be the "death knell" to classical humanism in Sweden (R-m, 1903, p. 257; see also Wennås, 1966,p. 372). Three years prior, the committee in charge of the reform had published a proposal bluntly stating that the continued "liberation" of the present culture from the "immediate dependence" of Antiquity had reached a point where Latin was no longer needed for bildning - the Swedish equivalent of the German Bildung (Liedman, 1993) that encapsulated the treasured process of self-cultivation and erudition still informing the entire

(C) Isak Hammar and Hampus Östh Gustafsson. Published by Emerald Publishing Limited. This article is published under the Creative Commons Attribution (CC BY 4.0) licence. Anyone may reproduce, distribute, translate and create derivative works of this article (for both commercial and non-commercial purposes), subject to full attribution to the original publication and authors. The full terms of this licence may be seen at http://creativecommons.org/licences/by/4.0/legalcode.

This paper forms part of a special section "The history of knowledge and the history of education", guest edited by Joel Barnes and Tamson Pietsch.

The authors are particularly grateful for suggestions and critical comments on this text from the anonymous reviewers and editors of this special issue, and also from Joakim Landahl and Petter Hellström.
Received 8 April 2021 Revised 29 September 2021 Accepted 5 November 2021 
HER

51,2

138

school system (Läroverkskommittén, 1902, p. 85). Refuting that classical education was the "indispensable condition" for the sustainment of higher cultivation that humanists often claimed, the committee maintained that said cultivation was now slowly but irrevocably distancing itself from its ancient counterpart (pp. 243-244).

The scholarly journal Pedagogisk Tidskrift ("Pedagogical Journal," 1865-1971) provides instructive examples of how the perceived irreverence shown toward classical humanism triggered a host of emotional responses from schoolteachers and university professors still convinced of the relevance of rigorous study of classical languages (Lindberg, 1987; Nilehn, 1975). For example, the philologist Vilhelm Knös stated that the committee's desire to violently "cut off the roots" of humanistic erudition (den humanistiska bildningen), and "implant a few branches" into the "straight tree trunk" of practical education (realskolan), would cause the former "irreparable harm" (1903, p. 168). Humanistic cultivation was by its very nature historically oriented, Knös argued, forging a "continuous and inextricable" link with ancient culture and society (p. 169). Without this historical link, he and his peers believed there could be no future for education in Sweden (see also Bergman, 1892, p. 118).

Hyperbole aside, looking back into the 19 th and ahead into the 20 th century, the historical self-reflexivity on display suggests larger processes at work. In fact, when taking the century-long publication run of Pedagogisk Tidskrift into account, the enduring negotiation over the contemporary educational value of maintaining a strong link with the ancient past via the curriculum of secondary schools forms a common thread, and one particularly entangled in competing views on reform and what was deemed "traditional" or "modern", respectively. From a larger perspective, such continuing clashes over the role of Antiquity in Swedish schools reveal a trajectory for the history of education as part of and later apart from a general history of the humanities. As we will argue, it therefore illustrates a symbiotic relationship between two hitherto separate fields in the general history of knowledge - the newly (re)formed history of humanities and history of education (Bod et al., 2016).

The journal in question is particularly suitable to provide our case in point. From its inception and up until the time of the new reform in 1905, Pedagogisk Tidskrift maintained a strong classical focus, regularly voicing support for maintaining the hegemony of classical languages in secondary schools. By the end of its publication run, however, the instructive and legitimizing bond with Antiquity had weakened, and the contributors increasingly explored alternative historical pasts that held the kernels of progressive visions of Swedish schools. Rather than brandishing the moorings of its ancient humanistic legacy, such postwar versions of Swedish history of education showcased Pedagogy as a discipline bound to the future, which, in this sense, was often contrasted to the traditional humanities that were criticized for being conservative, or untimely. Still, the journal in question remained a bastion of traditional views on Pedagogy, struggling to maintain its influence in the face of progressive ideals that guided a number of subsequent changes in Swedish educational politics.

In this article, we explore how crucial changes in the educational landscape triggered negotiation over the historical narratives of Pedagogy and education exemplified above. Although they never disappeared, these appeals, ostensibly intended to furnish a history of Swedish education as "rooted" in Antiquity, were later challenged by competing views of how to organize and write the history of education. By focusing on the content of the long-lived Pedagogisk Tidskrift, we are able to trace the overarching changes from a unifying history of humanities to a specialized history of education; providing a bird's eye view from the heyday of the humanities in the 19th century all the way to their alleged postwar "crisis" (e.g. Plumb, 1964; see also Östh Gustafsson, forthcoming). In the process, we highlight a number of instances where an ancient historical lineage was evoked in relation to changes in secondary school curricula, instructive of how historical knowledge could be mobilized, and contested, in order to construct legitimizing narratives. 


\section{A pedagogical arena of (historical) knowledge}

As one of the initiators, Historian and Minister of Ecclesiastical Affairs, F. F. Carlsson, managed to secure governmental grants for Pedagogisk Tidskrift when it was founded in 1865. Intended to replace Tidskrift för Sveriges läroverk ("Journal for Swedish Secondary Schools"), the new journal served as an important organ for secondary school teachers. These teachers often held $\mathrm{PhD}$ degrees and acted as authoritative experts within their respective fields. With their common educational base in Christianity and Latinity, they represented a constantly replenished cohort of influential civil servants. By taking on such a professional identity, secondary school teachers managed to form an effective coalition with the government, providing legitimacy for the entire educational organization well into the 20th century. Representing a "knowledge culture in diaspora", these teachers also stood for a wideranging societal circulation of humanistic knowledge thanks to their positions at secondary schools all over the country (Blomqvist, 1992, pp. 171-173; Thue, 2019, p. 172).

It was certainly no coincidence that a prominent historian paved the way for this new publication. As noted on a number of occasions in the journal itself, historical perspectives on education were given a prominent place in Pedagogisk Tidskrift right from the start (Editorial, 1944, p. 237; Wiberg, 1964, pp. 181). Published continuously until 1971, Pedagogisk Tidskrift provides a rare opportunity for inquiries into the modernization and democratization of the school organization and the shifting ideals of erudition (cf. Neem, 2019). Educational theory and curriculum studies have recently seen a strong "turn" to knowledge, and the various roles played by "knowledge traditions" in different national contexts of education have indeed been characterized as an essential topic of study, not least with regard to the curricular state of history (Chapman, 2021; Furlong and Whitty, 2017). As a related example, historian Fredrik W. Thue has pointed to the "epistemic nationalism" that influenced a number of humanities disciplines in Norway during the 19th century, based on a view of (Norwegian) history as a process of continuous development rooted in a general Nordic and European history of civilization (2019, p. 173). Bearing this in mind, we here focus on the function of historical knowledge and narratives in the negotiations concerning the role and state of Pedagogy in Sweden found in the journal in question; demonstrating that history was actively mobilized in order to provide structure and meaning to substantial parts of the secondary school curricula.

Although relying on a single source would appear to narrow our vision, Pedagogisk Tidskrift can be seen as providing a consistent seismograph for larger shifts, allowing us to maintain an elevated vantage point otherwise easily obscured. Moreover, by treating the journal as an arena of knowledge, a public forum moderated by members of a pedagogical community but open to a larger audience, we are using the continuity of Pedagogisk Tidskrift to our advantage. Historian Johan Östling has recently defined a public arena of knowledge as "a site for interactions between knowledge actors and their audiences" that demonstrates "a measure of stability and persistence" over time (Östling, 2020, p. 122). The extensive chronological scope allows us to track how actors of knowledge continuously intervened into this comparatively stable arena that hosted broad discussions on how the educational curricula (in secondary education primarily) should be designed.

"Historical knowledge" has been elaborated as a key analytical concept for the history of knowledge, characterized as a contingent category with high stakes (Jordheim and Shaw, 2020, pp. 16-18). Jordheim and Shaw suggest that history of knowledge should be viewed as "a sort of historical pragmatics, a study of the strength and origins of what has been worth knowing in the past, what knowing has had force, and how it came, albeit briefly, into that ripeness" (p. 18). In line with such a view, it is worth reminding that historical knowledge claims have regularly been mobilized as contingent - and contested - components for the ongoing struggle to demarcate and legitimize various (and mutable) academic fields or disciplines (c.f., Gieryn, 1999; Simon, 2019, pp. 76-78), in this case the emerging field of Pedagogy in relation to the diminishing ideal of classical humanism (Landahl and Larsson, 
HER

51,2

140

forthcoming). Historically, of course, the usefulness and influence of such claims have shifted. As the classical lineage gradually lost its authority, and in order to fill the void left by the canonical history of a unified humanities tradition, the editors of Pedagogisk Tidskrift eventually developed a distinctive form of self-reflexivity, continuously striving to historicize and define their own field of knowledge.

Sooner or later, scholarly disciplines or fields of research tend to turn to history in order to justify and make sense of the positions they have acquired in the academic landscape. The mobilization of historical narratives and knowledge is an integral part of canon formation: the search for "founding fathers" or "classics" (see, e.g., Eskildsen and Bod, 2019). Presently, such activities are visible within the expanding fields history of humanities and history of knowledge (see, e.g., Bod et al., 2016; Bod, 2020, pp. 1-2, 5-6; Daston, 2017, pp. 142-145; Dupré and Somsen, 2020). As we hope to demonstrate, there are good reasons why these endeavors should proceed in close dialogue with the history of education.

\section{Classical moorings and pedagogical unity}

The old Greeks and Romans, a Plato, an Aristotle, a Cicero, a Quintilian concerned themselves with the solution to many a problem, still treated today in our journal articles and in our teachers' meetings (S.G.C, 1870, p. 275).

In 19th century Sweden, as in Europe in general, the metaphorical roots with Antiquity were not only strong, but relatively unchallenged, due in large part to the common belief that Latin was the best tool to sharpen the mind and achieve the all-important harmonious progression and inner development of the student (see Bommel, 2015; Donnelly, 2002, pp. 545-546). Although consensus began to falter during the second part of the century, this tenet remained the lynch pin for legitimizing classical knowledge (Hammar, 2021b). Ancient Greek on the other hand, while still believed invaluable by most humanists, did not enjoy the same pedagogical value and was consequently more vulnerable to attempts at reforming the curriculum. It is therefore not surprising that when Pedagogisk tidskrift was launched in 1865, the very first article was a lamentation of the fact that Greek now had become optional for students. That Greek, "for centuries one of the main topics of secondary schools", was now dispensable must, according to the classicist and later editor in chief H. F. Hult, mean that its high regard in previous eras was either misplaced or that the task of modern schools had suddenly changed radically (Hult, 1865, p. 1).

To be sure, Swedish education had changed in the preceding decades (see, e.g., Karlsson Sjögren et al., 2019; Westberg, 2015), for one thing strengthening the natural sciences by introducing a parallel program based on realia next to the classical one (Hammar, 2021a, p. 9). Nevertheless, in Hult's and many of his fellow classicists' view, the charge of education was the same as it had been for a long time; the harmonious development of the mental faculties (Rabe, 1865; Waldenström, 1866; see also Hammar, 2019). This goal in turn enabled the tracing of a common history of the humanities "rooted" in Antiquity. Indeed, like the abovementioned Knös, authors of the era regularly used the tree metaphor to illustrate the profound value of classical ideas, values, and texts (e.g., M.D., 1884, p. 136). During the first half of the century, versions of this classically steeped history of the humanities - centered around the concept of humanistisk bildning ("humanistic self-cultivation") - could frequently be found in educational contexts and used to legitimize classical studies. Examples include overviews of foreign school systems (Schröder, 1828) and reform debates (Grubbe, 1829, p. 6). At the beginning of the century, it formed the basis for the first general Swedish history of education, published by the influential pedagogical scholar Broocman (1807; see Hammar, 2021b). Although flexible, the general narrative sketched the history of humanistic Bildung from ancient Greece and Rome, typically via the Middle Ages, the Renaissance, and the 
Reformation, and onwards, habitually centering on its pedagogical incarnation in Germany in the 18th century (see, e.g., Sandy, 1873). Thus, as long as bildning remained the cornerstone, history of education was closely aligned with general histories of the humanities (Hult, 1870, p. 13).

The historical lineage was the basis for a number of arguments in favor of the contemporary value of Antiquity. Some emphasized that the foundation of Pedagogy could be found in Ancient Greece and Rome, linked to the present through the canonical texts of ancient authors like Livy, Cicero, Homer, and Xenophon, and therefore that the past held the key to solving modern pedagogical challenges (see, e.g., Hult, 1870, pp. 14, 17; Linder, 1866, p. 191; O.S., 1881). Others believed that the unique features of the classical world could be harnessed for educational and moral purposes. For instance, in an article published during the first year, C. W. Linder, professor of Greek at Lund University, claimed that it was a misconception that classical languages were merely a tool for training the mind. It also had the parallel goal of providing the student with knowledge of ancient culture, which also was "a profound part of our own culture", and introducing the ancient way of thinking (Linder, 1865, p. 75; see also L, 1878, p. 168). In general terms, it was commonly argued that learning Latin and Greek "opened" the ancient world to the student, who could then experience the nobleness and spiritual achievement of "the Old ones" firsthand (e.g., Broocman, 1810, pp. 12-13; see also Adler, 2020, p. 61). Moreover, since many saw the languages themselves as infused with the spirit and culture of Antiquity, this educational model directly communicated these values to the student (e.g., Uhlig, 1897, p. 300). One commentator in Pedagogisk Tidskrift, Julius af Sillén, associate professor of Greek and teacher of classical languages for secondary schools, even purported that Latin hid centuries of knowledge, incorporated from subsequent periods of history (Sillén, 1886, p. 102). More drastically, one (anonymous) author proclaimed that classical humanism provided the "Ariadne's thread" out of the confusing "maze" of the present, claiming that it would be "spiritual suicide" to expel classical languages from secondary schools (O., 1890, pp. 98, 100).

As a general pattern for the circulation of educational ideas in 19th-century Sweden, the proposals from a seemingly perpetual string of educational committees triggered responses in the public sphere (Hammar, 2018). For instance, when in 1884, the latest in a long line of educational committees argued that the pedagogical value of Latin had been overstated and proposed a reduction of the number of hours allocated to its study, the journal published a number of remonstrances from concerned classicists. But the reform proposal itself also demonstrated the lingering influence of classical humanism. Although the proposal effectively questioned Latin as the best tool to sharpen the mind, the committee did not refute the historical narrative empowering classical studies - the existence of an invisible bond between Antiquity and modern society. In fact, the committee seemed determined to strengthen this link, asserting that modern erudition had grown from its ancient counterpart and that no one could understand their own age and its culture without knowing Antiquity and the conditions upon which this culture rested (Läroverkskomitén, 1884, pp. 57-58). It was the view of the committee that this bond, and not the classical languages in themselves, gave classical education its value. Although they acknowledged that learning Greek and Latin was the ideal path to ancient culture, translations could also serve the same purpose and still adhere to modern demands of vocational and scientific training. Classical humanists, of course, were not convinced, although the aforementioned Hult, in a critical review of the proposal in Pedagogisk Tidskrift, also quoted the committee's paragraph about the invisible bond between modern and ancient culture and called it "so true and so beautiful" that he did not want to risk distorting it by paraphrasing (Hult, 1885, p. 206).

But with the reform proposal of 1902 and the subsequent school reform of 1905, even this compromise seemed to have failed and, in the following years, some classicists began to realize that the battle was lost. It is futile, wrote Clemens Cavallin, philologist and teacher of 
HER

51,2

142

Greek and Latin, in Pedagogisk Tidskrift in 1904, to oppose what has become a "compact antipathy" toward classical languages (Cavallin, 1904, p. 389). Other advocates of classical humanism, fearing that the ancient roots were about to be severed in the name of modernity, tried to strengthen them. A deeper and more systematic knowledge of the history of human culture was not possible without classical languages and the histories of Greece and Rome, according to philologist Axel Jacobsson (Jacobsson, 1905, p. 432). One year later the frequent defender of classical study, Ingvar Olsson, whose main vocation, like Jacobsson and many other of the contributors, was that of teacher of classical languages in secondary schools, held that one needs to understand the history of knowledge, the "growth of the tree of culture from its sprout", which is not possible unless one knows the languages and can read the canonical works that have spiritually bridged nations and generations (Olsson, 1906, p. 371). Others prescribed a shift in focus from the study of grammar to ancient literature and history, still felt by many to be profoundly "weaved into our culture" (Olsson, 1908, p. 411; see also Olsson, 1909, pp. 381-382; Samuelsson, 1907, p. 25).

One final example might suffice to illustrate the desperation of classicists at the time. In 1911, the Swedish Society of Humanists filed a petition addressed to the King, regarding classical education. The petition was signed by one of the editors of Pedagogisk Tidskrift and printed in its entirety in the journal. In concordance with many of the journal's most fervent advocates, the petition maintained that the humanistic erudition of Antiquity had such a trajectory that to this very day it remained a most important factor in European high culture. A "deeper humanistic erudition (bildning)" should thus be considered "inseparably linked" to its ancient counterpart. The modern organization of education must therefore, the petition declared, make sure that "a direct link" with ancient erudition be maintained (Sahlin et al., 1911, p. 111). In the 20th century, however, the ancient past was about to give way to the future as the main point of reference in discussions on the structure of educational curricula.

\section{The clash of "traditional" unity and "modern" specialization}

Although the reform in 1905 was explicitly described in Pedagogisk Tidskrift as the culmination of the struggle between classical humanism and realia that characterized the 19th century, the clash in fact echoed throughout the entire publication run (Larsson, 1950, pp. 158-159; Larsson, 1966, p. 82; Ribbner, 1967, p. 57). One might even say that the tensions seamlessly morphed into a bifurcation between the humanities and the natural sciences, or as they later became known under the term coined by C. P. Snow, "the two cultures" (Snow, 1959). However, it is worth noting that classicists during the preceding century were not only hostile toward natural science, but also objected to humanistic subjects such as modern languages (Thue, 2019, p. 173). Nonetheless, as public appreciation for the benefits of the natural sciences grew (increasingly seen as an important part of progressive visions), classicism, and the humanities in general, were in contrast not seen as fully corresponding to the requirements of "modern society", which was reflected in the negotiations over school curricula (cf. Lövheim, 2006, pp. 86-89). Despite having been a bulwark for classical humanism, such general criticisms resounded also in Pedagogisk Tidskrift. In 1916, for instance, professor of English R. E. Zachrisson accused fellow humanities teachers of being too sentimental or nostalgic, desiring to master all fields of knowledge - a quest deemed "impossible to realize in our own time of ceaseless progression and constant re-evaluations" (Zachrisson, 1916, p. 312). And in debates preceding a new school reform in 1927, there were explicit wishes that the responsible commission should dare to break with the one-sided traditions of humanistic learning as these were accused of not effectively dealing with social realities (Jaederholm, 1924, pp. 201, 215; Petrini, 1918, pp. 289-290). It was even pointed out 
that "old" humanities scholars and teachers had to go through a process of transformation unless their subjects should be set aside (Landtmanson, 1922, p. 45).

In response to the reform in 1927, Pedagogisk Tidskrift published a number of articles suggesting that the humanities had no choice but to try to keep up with the progressive and positivistic natural sciences. Legitimacy was no longer found in the past. While science and technology were credited for having raised modern culture higher than its ancient counterpart, the classical humanist was portrayed as a "ghost" or "stranger" in the modern world, busy with "worthless fandangle". A "modern scientific culture" on the other hand, would aid the emancipation from the "iron grip of Antiquity" (Petrini, 1934, pp. 54-55, 60-61). This view, phrased by a teacher in Mathematics and Physics, was probably quite extreme in the context of this journal. Nevertheless, teleological interpretations of scientific specialization, at the cost of a universal concept of Bildung, fueled calls for an abandonment of the remnants of the old curricular dominance of classical humanism and a dated understanding of the history of the humanities. This attitude was particularly visible after the editorial shift in the 1930s when Adolf Söderlund, secondary school teacher as well as specialist on German and Pedagogy, replaced historian Vilhelm Vessberg.

While occasionally these ambitions to break the bonds of tradition were still met with fierce criticism within the journal by those striving to defend "the old humanistic gymnasium" (Armini, 1928, p. 98), it is worth noting that the diminishing influence of Greek and Latin, as well as ancient history and literature, was not only explained by shifting public attitudes, but also related to practical organizational dilemmas. As new content had to be synchronized with existing syllabuses, specialization and heterogenization of the very idea of bildning spurred intense competition for space in the curriculum and the future societal influence it entailed. The political ambitions of the interwar period, facilitating a more progressive society through continuous reforms, added friction to these conflicting ideals (Wennerholm, 2008, p. 140). By way of example, when after the secondary school reform of 1927, girls were allowed to enter general secondary schools along with an increasing enrollment of children with working class backgrounds, some actors doubted whether these new cohorts were capable of handling the traditional forms of schooling. The new ideas of reform were hardly seen as congenial with time-worn ideals of classical humanism.

For one thing, throughout the 20th century, a number of articles in Pedagogisk Tidskrift expressed a fear that a broadened curriculum in secondary education would not allow in-depth studies, in turn detrimental to the study of classical languages. As regarded Latin, it was pointed out that teachers and students faced a rushed and stressful situation due to the new time constraints put on teaching. Similar concerns were raised regarding History, which was described as particularly neglected by the 1927 reform. There were fears that significant parts of the past would have to be excluded, leaving the pupils with isolated facts, or a fragmented synchronism at the expense of extended diachronic perspectives (Körner, 1933, pp. 162-164; Larsson, 1945, p. 131; Sjövall, 1939, pp. 217-222). At the same time, several authors welcomed this turn. The regular contributor, historian and teacher Olof Johnsson, for instance, claimed that: "In our endeavors to conquer the millennia we are losing our own time - and ourselves" (Johnsson, 1914, p. 338). In this vein, historical narratives were by many expected to have a direct bearing on contemporary problems.

In view of such demands, it is possible to distinguish an escalating conflict between the traditional historical knowledge and narratives cherished in Pedagogisk Tidskrift and novel forms of Pedagogy - the latter strongly calling for a pragmatist use of history. A growing number of pedagogues stressed the importance of history teaching to be vivid and stimulate children's imagination. But if school history truly should live up to such requirements, it was concluded that its content had to be reduced. This became particularly acute in the negotiations of the role of classical humanism and ancient history (see Andolf, 1972, p. 289). For instance, it was doubted whether young people really were able to transcend the distance 
HER

51,2

144

to Antiquity and enter this "different, remote world". As one author suggested, perhaps it would be better to focus on a more relatable Nordic history (Ninck, 1924, p. 169). Whenever chronological curtailment was discussed, ancient and medieval history were the periods first suggested to be left out from secondary school courses; after the 1927 reform, they were expected to be covered in one year, which was deemed impossible by several writers in Pedagogisk Tidskrift. This shrinking of the historical "space of experience", to borrow Koselleck's term (2004), was described as a pattern increasingly visible with every political reform. To argue that a historical link with Antiquity had special relevance became more and more difficult.

The development toward reduced historical timeframes within various subjects in secondary education was seen as especially detrimental for teachers in classical languages: "The time is past, when it was possible at all for an ardent secondary schoolteacher to supply his pupils with any genuine knowledge in either Latin (and Greek) or in History. One has to be content with doing as well as one can and try not to worry about the decay of humanistic cultivation" (Torius, 1933, pp. 136-137). Believing the classical heritage to still be relevant, several contributors strongly protested, arguing that the past, present, and future should be intimately connected, and this required space for extended diachronic perspectives. As one contributor, classicist and secondary school teacher Erik Tidner, phrased it in 1944, there was a fear that history would be "truncated" as the influence of ancient history in secondary education was reduced (Tidner, 1944, p. 84). It was not only formal bildning, but also the various temporal segments of history, that were expected to form an organic whole in the context of education. Such an attitude would become particularly strained in the postwar period.

\section{Postwar partings and diverging histories}

The decades following the end of the Second World War saw profound changes to the school system and teachers' education, including the transformation of secondary schools following a major reform in 1965. Secondary schools were now to be open to all segments of the population, rather than limited to a homogeneous elite. This era of rapid educational expansion in Sweden was occasionally described as exceptionally ahistorical by contemporary actors. The obsession with the future and the materialistic progress of the welfare state dominated the politics of knowledge and invigorated the already common critique of bildning based on the humanities (Osth Gustafsson, 2020a). Moral values were claimed to be stuck with the past as historical perspectives got deprioritized in the work of various commissions, leading up to new educational reforms in the 1960s and 1970s (cf. Sjöstrand, 1967, p. 122). The increasingly autonomous discipline of Pedagogy, on the other hand, was undoubtedly connected to the future on a discursive level in contemporary politics. Previous research has noted how the Swedish social sciences, Sociology in particular, were considered modern and progressive (see, e.g., Larsson and Magdalenić, 2015, pp. 6, 12-16, 88). This was the case also for Pedagogy (and Psychology), clearly influenced by Sociology at this point. Taken together, these disciplines were embraced by politicians and expected to contribute to the future development of the welfare state (Bernhagen, 1959, p. 51). A clear direction of time was thus assumed as these subjects promised the key to a progressive future for this society.

It is hardly surprising that the ancient past was not easily merged with these developments. Antiquity was no longer a primary point of reference within Pedagogy. Ancient authorities increasingly had to share space with more modern pedagogues or philosophers, such as Pestalozzi and Rousseau, or, for that part, Spencer (cf. Söderlund, 1958, pp. 78-88, 92-93). The previously mentioned Broocman was, for instance, seen as a pioneer and harbinger of reform, but the strong belief once held by this $19^{\text {th }}$-century pedagogue in the 
instructive and moral power of Antiquity was no longer emphasized (Agrell, 1960; Larsson, 1946; Wiberg, 1939; see also Hammar, 2021b).

Still, classical humanism had its defenders. In 1964, a faint echo of Hult's inaugural article on the dispensation from Greek 100 years earlier could be heard when one contributor similarly accused politicians of impairing secondary education with their hostile approach toward ancient history and, in the long run, the entire curriculum of the humanities (Solders, 1964, pp. 302, 323). This relatively common lamentation of being set aside reflected a process of political alienation or discursive marginalization in postwar Sweden (Osth Gustafsson, 2018, 2020b). Indeed, not only did Sweden import the "two cultures" debate (Eldelin, 2006), but the period was also characterized by separations. For instance, the humanities and the social sciences parted ways institutionally, as the latter were organized into a faculty of their own in 1964. The pressure on academia to prove its social usefulness increased, leading to a number of attempts to differentiate education and tie its different branches closer to specific vocational areas. The idea of a universal notion of bildning, for so long based on classical humanism, thus lost additional ground, basically colliding with new practical expectations of "modern" education.

In connection to this, a widening gap between History and Pedagogy was also visible, as the former ceased to play a dominant part in pedagogical scholarship (see, e.g., Sainio, 1966, p. 120). In the 1964 centennial issue of Pedagogisk Tidskrift, it was concluded that discussions of relevance to the core discipline of History had more or less vanished in the journal, particularly after 1945, while articles focusing on the history of Pedagogy thrived (Kjellin, 1964, pp. 371-372). The journal thus began to turn into an arena for trained pedagogues as the formal ties between History and Pedagogy were cut. This did not mean, however, that historical knowledge and narratives ceased to inform the legitimization of Pedagogy. As the discipline became increasingly independent and firmly institutionalized at Swedish universities throughout the 20th century - the first professorships were created already in the 1910s (Kroksmark, 1991) - its leading proponents began to orient themselves in novel ways in order to secure their new positions. They turned to their own, specialized accounts of history, but parted ways with History as a discipline. In a way similar to the postwar development in Norwegian secondary education, historical knowledge lost its former integrating role in this respect, and rather followed separate trajectories within the humanities, social sciences, and Pedagogy, respectively (Thue, 2019, pp. 167). An illustrative example of this development is the emergence of history of education as a professional field in $20^{\text {th }}$-century Sweden, with close ties to Pedagogy (Westberg, 2017, pp. 19-24).

A blossoming interest in history of education or "school history" had been noted in Pedagogisk Tidskrift already during the interwar period (Beckman, 1932, p. 315). This interest would eventually explode after the Second World War, and was welcomed by editor Söderlund who hoped it would function as an antidote to the strong ahistorical currents at the time (Söderlund, 1958, p. 65). Not least, the trend was solidified thanks to the regular contributions to the journal by Pedagogy professor Wilhelm Sjöstrand, famous for an ambitious work on the history of Pedagogy in three volumes. If Pedagogisk Tidskrift previously had hosted attempts to defend classical humanism and a unified history of the humanities, combined with great reverence for the academic discipline of History, the actors active on this arena now singled out the more specific history of Pedagogy or education (see Wennås, 1966, p. 368). To be sure, Antiquity and classical culture were still part of this new focus. Sjöstrand noted its prominent state in previous historiography of education and concluded that it was still of vital importance, but he also pointed out that origins of "historical-pedagogical knowledge" stretched even further back in time, to oriental civilizations (Sjöstrand, 1954, p. 7). Even if Antiquity survived in this type of historiography, it had ceased to play the unique part it had at the inauguration of Pedagogisk Tidskrift in the mid-19th century, when the paradigm of classical humanism put it center stage. 
HER

51,2

146

Ironically, Pedagogisk Tidskrift was forced to terminate its publication in 1971 (following decades of financial hardships), at the very point when Pedagogy and new forms of teachers' education seemed to triumph, also coinciding with a major reform of secondary education that included a new curriculum (Lgy 70). With its conservative profile, the journal stood out as an arena associated with the promotion of certain traditional forms of historical knowledge perhaps appearing as too stable for its own good in this respect? When a new editorial board was appointed in 1962 and Adolf Söderlund left his post after 28 years of service, it was noted that the journal struggled to adapt to the rapid changes of the organization of Swedish education, and also that a number of specialized pedagogical publications were increasing the competition for subscribers (Söderlund, 1961, p. 182). This development may be compared to the different fate of an equivalent Norwegian journal for Pedagogy, Norsk pedagogisk tidsskrift, that managed to adapt to conceptual changes and the expansion of tasks seen as relevant to the increasingly professionalized discipline of Pedagogy in the postwar period (Jarning, 2016, pp. 247-248, 259). For the Swedish journal - less prone to change due to its strong generalist ambitions tied to the 19th-century legacy of universal bildning - it was apparently more difficult to demonstrate its raison d'etre in this new reality. The main contributors to this long-standing publication (almost solely men) seemed rooted in an abandoned regime of knowledge, regularly taking on conservative positions and questioning the progressive welfare politics. Pedagogisk Tidskrift was thus replaced by other journals, seemingly representing a new pedagogical paradigm.

As Sweden eventually saw a breakthrough of the familiar crisis discourse of the humanities in the 1970s, new scholarly generations sought to combat the alleged marginalization of these subjects by means of mobilizing contrasting historical narratives in order to demonstrate how things could be different. As one literary scholar described this aspiration: "Change can be achieved through the conflicts and ruptures in history. One must find the root in order to pull it out" (Thavenius, 1981, pp. 245). For postwar Pedagogy, this form of retrospective mobilization was certainly relevant - manifested in Pedagogisk Tidskrift in the creed that "understanding a scholarly discipline, means to understand its history" (Editorial, 1962, p. 2). Pedagogues and school historians however discarded a traditional history of humanities and pursued their own history, displaying a confidence that the discipline of Pedagogy was one of the most vital branches of the modern tree of knowledge.

\section{Conclusion: common "roots" or separate "trunks"?}

The liberal arts are the roots of our tree of learning. But the trunk has been divided into several trunks, and the humanist watches how medicine and law spring up next to his trunk. Beneath him, he sees an ancient sprout, theology, but past him, the trunks of social science and technology and natural science spring. (Brunius, 1963, p. 26)

The above quotation, from a study guide for humanities students written by an art historian in the mid-20th century, neatly captures the shift investigated in this article. As illustrated by recent research, tree metaphors have served to naturalize divisions and hierarchies of knowledge for centuries (Hacking, 2007; Hellström, 2019), and they are still employed. As the quotation underscores, however, the view of education and cultivation as an inseparable, organic system, united by classical humanism and ancient history, was replaced by a divided hierarchy of competing "trunks" or "branches", allegedly stretching for the future. The continuous discussions in Pedagogisk Tidskrift can be seen as an expression of the phantom pains among a segment of educational scholars and teachers, lamenting the perceived devaluation of specific forms of (ancient) knowledge and, most importantly, the alleged loss of a unity of knowledge once taken for granted. 
Even from a wider international perspective, it has been noted that the humanities for a long time appeared as politically conservative with close ties to the Counter-Enlightenment, while the social sciences, Psychology, and Pedagogy were attributed with progressive connotations (cf. Leezenberg, 2018, p. 178). In a democratic society whose politics of education particularly emphasized equality and the erasure of classes as primary goals, it was apparently difficult to reach consensus regarding the minimum requirements of erudition. Swedish secondary school teachers in the 19th century have been characterized as a homogeneous elite, even if less elitist compared to other European countries (Florin and Johansson, 1993). The long educational "revolution" in terms of expansion however, strained the attempts to keep traditional ideals of cultivation alive as new pressures emerged, calling for an adaption to democratic diversity, equality, and vocational differentiation that saw pedagogical ideals and perspectives replace the former function of history as a key curricular chord (cf. Larsson, 2019). The relatively strong progressive form of modernism that was championed by Swedish politicians and "reform technocrats" eventually appeared as a threat to the traditional values and lifeworld of teachers educated within the paradigm of classical humanism (cf. Lundin and Stenlås, 2015).

While many characteristics of this struggle are well known, as well as Pedagogy's formation and successive departure from Philosophy and Psychology, previous research has paid less attention to the shifting role of legitimizing historical narratives as a factor behind the development of this discipline. Abandoning the traditional modes of navigating within a general space of experience of the humanities at large, pedagogues eventually sought to construct an autonomous canon and disciplinary-oriented origin story, thus mobilizing a different body of historical knowledge. The past was constantly present on arenas like Pedagogisk Tidskrift, but the way it was employed for the purpose of legitimization shifted as classical humanism and ancient history were ascribed less importance. This trajectory marks an important feature for the eventual marginalization of the humanities in $20^{\text {th }}$-century Sweden as it was not only Pedagogy that parted ways from their former coalition partners. Separate institutions were also established for social sciences and journalism, previously associated with the humanities. In this process, "the humanities" thus lost a number of central links to the job market (e.g., through the education of schoolteachers) and wider society (cf. Landahl and Larsson, forthcoming; see also Grøtta, 2019). Taken together, this reflects a loss of institutional and discursive space for the humanities in intellectual as well as public contexts, for instance as new alternative and specialized arenas (such as journals) were opened for a renegotiation of the societal legitimacy of knowledge.

A narrow focus on the oscillations of classical humanism through the prism of Pedagogisk Tidskrift has afforded us a bird's eye view that, albeit eschewing complicated developments over a long period of time, we believe has brought attention to some previously unrecognized lines of development that shed new light on the relationship between history of education and a wider history of knowledge. Future inquiries into similar processes of negotiation would benefit from transnational comparisons and concrete investigations of historical content and curricular hierarchies.

Shifting disciplinary demarcations in the histories of education, humanities and/or knowledge are indeed urgent topics of research. While the alternating boundaries between the humanities and sciences have received considerable interest recently (see, e.g., Krämer, 2018), the relationship with education is still in need of more attention. We believe it worthwhile to look at the history of education as part and parcel of a more general history of humanities and knowledge, instead of as separate fields of inquiry. Surely the respective research traditions have much to gain from joining forces in exploring how these "branches" of knowledge are intertwined - even if their common "roots" may have been severed in the past. 
HER

51,2

148

\section{References}

Adler, E. (2020), The Battle of the Classics: How a Nineteenth-Century Debate Can Save the Humanities Today, Oxford University Press, Oxford.

Agrell, J. (1960), "Den pedagogiska debatten i Sverige 1807-1820”, Pedagogisk Tidskrift, pp. 11-24.

Andolf, G. (1972), Historien på gymnasiet: undervisning och läroböcker 1820-1965, Esselte studium, Stockholm.

Armini, H. (1928), “Kring latinstudiet i gymnasiet”, Pedagogisk Tidskrift, Vol. 64, pp. 97-104.

Beckman, B. (1932), "Uppfostran genom undervisning”, Pedagogisk Tidskrift, Vol. 68, pp. 315-327.

Bergman, J. (1892), "Latinet i framtidens skola”, Pedagogisk Tidskrift, Vol. 28, pp. 117-123.

Bernhagen, M. (1959), "Martin Uhlin: fostran förr och nu”, Pedagogisk Tidskrift, Vol. 95, pp. 50-51.

Blomqvist, G. (1992), Elfenbenstorn eller statsskepp? Stat, universitet och akademisk frihet $i$ vardag och vision fràn Agardh till Schück, Lund University Press, Lund.

Bod, R. (2020), "How to open pandora's box: a tractable notion of the history of knowledge", Journal for the History of Knowledge, Vol. 1 No. 1, pp. 1-7, doi: 10.5334/jhk.2.

Bod, R., Kursell, J., Maat, J. and Weststeijn, T. (2016), “A new field: history of humanities”, History of Humanities, Vol. 1 No. 1, pp. 1-8, doi: 10.1086/685056.

Bommel, B.V. (2015), Classical Humanism and the Challenge of Modernity: Debates on Classical Education in 19th-Century Germany, De Gruyter, Berlin.

Broocman, C.B. (1807), Berättelse om Tysklands undervisningsverk ifrån dess äldsta intill närvarande tider, Marquard, Stockholm.

Broocman, C.B. (1810), "Om det offentliga läroverket”, Magasin För Föräldrar Och Lärare, Vol. 5, pp. $1-24$.

Brunius, T. (1963), Handbok for humanister, Lindblads, Stockholm.

Cavallin, C. (1904), “Grekiskan som skolämne efter läroverksreformen”, Pedagogisk Tidskrift, Vol. 40, pp. 389-398.

Chapman, A. (2021), "Introduction: historical knowing and the "knowledge turn", in Chapman, A. (Ed.), Knowing History in Schools: Powerful Knowledge and the Powers of Knowledge, Knowledge in the Curriculum, UCL Press, London.

Daston, L. (2017), "The history of science and the history of knowledge", KNOW, Vol. 1 No. 1, pp. 131-154, doi: 10.1086/691678.

Donnelly, J.F. (2002), "The 'humanist' critique of the place of science in the curriculum in the nineteenth century, and its continuing legacy", History of Education, Vol. 31 No. 6, pp. 535-555, doi: 10.1080/00467600210167073.

Dupré, S. and Somsen, G. (2020), "Forum: what is the history of knowledge?", Journal for the History of Knowledge, Vol. 1, pp. 1-1, doi: 10.5334/jhk.29.

Editorial (1944), "Efter 80 årgångar”, Pedagogisk Tidskrift, Vol. 80, pp. 237-239.

Editorial (1962), “Anmälan”, Pedagogisk Tidskrift, Vol. 98, pp. 1-3.

Eldelin, E. (2006), 'De två kulturerna' flyttar hemifrån: C. P. Snows begrepp i svensk idédebatt 19592005, Carlsson, Stockholm.

Eskildsen, K.R. and Bod, R. (2019), "The forgotten curriculum of the humanities", History of Humanities, Vol. 4 No. 2, pp. 219-227, doi: 10.1086/704806.

Florin, C. and Johansson, U. (1993), 'Där de härliga lagrarna gro. . .': Kultur, klass och kön i det svenska läroverket 1850-1914, Tiden, Stockholm.

Furlong, J. and Whitty, G. (2017), "Knowledge traditions in the study of education", in Whitty, G. and Furlong, J. (Eds), Knowledge and the Study of Education: an International Exploration, Symposium Books, Didcot, pp. 13-57. 
Gieryn, T.F. (1999), Cultural Boundaries of Science: Credibility on the Line, University of Chicago Press, Chicago.

Grøtta, V. (2019), The Transformation of Humanities Education: the Case of Norway 1960-2000 from a Systems-Theoretical Perspective, Global Studies and Theory of Society 3, transcript, Bielefeld.

Grubbe, S. (1829), "Reservation", Betänkande af comitén till öfverseende af rikets allmänna undervisningsverk, Nestius, Stockholm.

Hacking, I. (2007), “Trees of logic, trees of porphyry”, in Heilbron, J. (Ed.), Advancements of Learning, Olschki, Florence, pp. 221-261.

Hammar, I. (2018), "Conflict, consensus, and circulation: the public debates on education in Sweden, c. 1800-1830", in Östling, J., Sandmo, E., Larsson Heidenblad, D., Nilsson Hammar, A. and Nordberg, K.H. (Eds), Circulation of Knowledge: Explorations in the History of Knowledge, Nordic Academic Press, Lund, pp. 144-159.

Hammar, I. (2019), "A conflict among geniuses: challenges to the classical paradigm in Sweden, 1828-1832”, History of Education, Vol. 48 No. 6, pp. 713-730, doi: 10.1080/0046760X.2018. 1543458.

Hammar, I. (2021a), "Classical nature: natural history, classical humanism, and the value of knowledge in Sweden, 1800-1850", Journal of the History of Knowledge, Vol. 2 No. 1, pp. 1-14, doi: 10.5334/jhk.2.

Hammar, I. (2021b), "From Germany with love: circulating formale Bildung in the early 19th century", History of Humanities, Vol. 6 No. 2, pp. 603-615.

Hellström, P. (2019), Trees of Knowledge: Science and the Shape of Genealogy, Acta Universitatis Upsaliensis, Uppsala.

Hult, H.F. (1865), "Bidrag till lösning af frågan om Grekiskans ställning vid Elementarläroverken", Pedagogisk Tidskrift, Vol. 1, pp. 1-8.

Hult, H.F. (1870), “Om uppfostran och undervisning”, Pedagogisk Tidskrift, Vol. 6, pp. 13-21.

Hult, H.F. (1885), "I latinfrågan. Ett bidrag till granskning af läroverkskomiténs betänkande", Pedagogisk Tidskrift, Vol. 21, pp. 193-213.

Jacobsson, A. (1905), "Om det klassiska gymnasiets nödvändighet i vår tid”, Pedagogisk Tidskrift, Vol. 41, pp. 431-434.

Jaederholm, G.A. (1924), "En granskning av skolkommissionens förslag", Pedagogisk Tidskrift, Vol. 60, pp. 193-216.

Jarning, H. (2016), "Det pedagogiske kunnskapsområdet og Norsk pedagogisk tidsskrift", Norsk Pedagogisk Tidsskrift, Vol. 100 No. 4, pp. 247-260.

Johnsson, O. (1914), “Om bildning: strödda tankar”, Pedagogisk Tidskrift, Vol. 50, pp. 335-343.

Jordheim, H. and Shaw, G.D. (2020), "Opening doors: a turn to knowledge”, History and Theory, Vol. 59 No. 4, pp. 3-18, doi: 10.1111/hith.12179.

Karlsson Sjögren, A., Larsson, E. and Rimm, S. (2019), "Agents and subjects: schooling and conceptions of citizenship in early nineteenth-century Sweden", History of Education, Vol. 48 No. 3, pp. 297-316, doi: 10.1080/0046760X.2018.1541482.

Kjellin, G. (1964), "Diskussion kring historieämnet”, Pedagogisk Tidskrift, Vol. 100, pp. 358-372.

Knös, V. (1903), "Läroverkskommitténs betänkande och den humanistiska bildningen”, Pedagogisk Tidskrift, Vol. 39, pp. 161-188.

Körner, R. (1933), "Läroboksproblemet i historia”, Pedagogisk Tidskrift, Vol. 69, pp. 161-178.

Koselleck, R. (2004[1979]), Futures Past: On The Semantics of Historical Time, transl. Keith, T., Columbia University Press, New York, NY.

Krämer, F. (2018), "Shifting demarcations: an introduction", History of Humanities, Vol. 3 No. 1, pp. 5-18, doi: $10.1086 / 696298$. 
HER

51,2

Kroksmark, T. (1991), Pedagogikens vägar till dess första svenska professor, Acta Universitetatis Gothoburgensis, Gothenburg.

L (1878), "Böra icke våra latinska skolgrammatikers omfång minskas?”, Pedagogisk Tidskrift, Vol. 14, pp. 165-174.

Landahl, J. and Larsson, A. (forthcoming), "Pedagogy and the humanities: changing boundaries in the academic map of knowledge, 1860s-1960s", in Ekström, A. and Östh Gustafsson, H. (Eds), The Humanities and the Modern Politics of Knowledge: the Impact and Organization of the Swedish Humanities 1850-2020, Amsterdam University Press, Amsterdam.

Landtmanson, S. (1922), "Våra läroverks 'sjunkande nivå”, Pedagogisk Tidskrift, Vol. 58, pp. 44-48.

Läroverkskomitén (1884), Läroverkskomiténs underdåniga utlåtande och förslag angående organisationen af rikets allmänna läroverk och dermed sammanhängande frågor, Norstedt, Stockholm.

Läroverkskommittén (1902), Betänkande, Stockholm, Vol. 1.

Larsson, K. (1945), “Aktuella synpunkter på realskolans historieundervisning”, Pedagogisk Tidskrift, Vol. 81, pp. 122-136.

Larsson, K. (1946), "Reformtankar i svensk skolpolitik 1809-1820", Pedagogisk Tidskrift, Vol. 82, pp. 179-196.

Larsson, K. (1950), "Våra skolreformer och deras socialpolitiska bakgrund", Pedagogisk Tidskrift, Vol. 86, pp. 146-159.

Larsson, K. (1966), "Kristendomsundervisningen inför skolreformerna”, Pedagogisk Tidskrift, Vol. 102, pp. $82-88$.

Larsson, E. (2019), “1800-talets utbildningsrevolution”, Historisk Tidskrift, Vol. 139 No. 4, pp. 741-750.

Larsson, A. and Magdalenić, S. (2015), Sociology in Sweden: A History, Palgrave Macmillan, Basingstoke.

Leezenberg, M. (2018), History and Philosophy of the Humanities: an Introduction, Amsterdam University Press, Amsterdam.

Liedman, S.E. (1993), "In search of Isis: general education in Germany and Sweden", in Rothblatt, S. and Wittrock, B. (Eds), The European and American University since 1800, Cambridge University Press, Cambridge, pp. 74-106.

Lindberg, B. (1987), Humanism och vetenskap: den klassiska filologien i Sverige fràn 1800-talets början till andra världskriget, Lärdomshistoriska Samf., Grillby.

Linder, C.W. (1865), "Om den methodiska behandlingen af de klassiska språken vid Elementarläroverken”, Pedagogisk Tidskrift, Vol. 1, pp. 65-76.

Linder, C.W. (1866), “Om metriska öfningar i Latin och Grekiska”, Pedagogisk Tidskrift, Vol. 2, pp. 191-199.

Lövheim, D. (2006), Att inteckna framtiden: läroplansdebatter gällande naturvetenskap, matematik och teknik $i$ svenska allmänna läroverk 1900-1965, Uppsala Studies in History of Ideas 33, Acta Universitatis Upsaliensis, Uppsala.

Lundin, P. and Stenlås, N. (2015), "The reform technocrats: strategists of the Swedish welfare state, 1930-1960", in Vandendriessche, J., Peeters, E. and Wils, K. (Eds), Scientists' Expertise as Performance: between State and Society, 1860-1960, Pickering and Chatto, London, pp. 135-146.

M.D (1884), “Antingen - eller”, Pedagogisk Tidskrift, Vol. 20, pp. 132-137.

Neem, J.N. (2019), "Liberal education confronts the rise of democracy: yale's reports of 1828", History of Humanities, Vol. 4 No. 2, pp. 401-422.

Ninck, V. (1924), "Skolans mekanisering”, Pedagogisk Tidskrift, Vol. 60, pp. 161-175.

Nilehn, L.H. (1975), Nyhumanism och medborgarfostran: åsikter om läroverkets målsättning 18201880, Gleerup, Lund. 
O. (1890), "Om de klassiska språkens och speciellt grekiskans förhållande till den moderna bildningen”, Pedagogisk Tidskrift, Vol. 6, pp. 91-100.

Olsson, I. (1906), “Universitetsexamenskommittén och latingymnasiet”, Pedagogisk Tidskrift, Vol. 42, pp. 367-371.

Olsson, I. (1908), "Något om åskådningsmateriel vid undervisning i klassiska språk", Pedagogisk Tidskrift, Vol. 44, pp. 411-414.

Olsson, I. (1909), “Latinet på gymnasiet: historik, metoder, kurser”, Pedagogisk Tidskrift, Vol. 45, pp. 377-402.

O.S (1881), "Om ungdomens uppfostran i den fornklassiska tiden", Pedagogisk Tidskrift, Vol. 17, pp. 1-9.

Östh Gustafsson, H. (2018), "The discursive marginalisation of the humanities: debates on the humanist problem in the early 1960s Swedish welfare state", History of Humanities, Vol. 3 No. 2, pp. 351-376, doi: 10.1086/699299.

Östh Gustafsson, H. (2020a), Folkhemmets styvbarn: humanioras legitimitet $i$ svensk kunskapspolitik 1935-1980, Daidalos, Gothenburg.

Östh Gustafsson, H. (2020b), "Mobilizing the outsider: crises and histories of the humanities in the 1970s scandinavian welfare-states", in Östling, J., Olsen, N. and Larsson Heidenblad, D. (Eds), Histories of Knowledge in Postwar Scandinavia: Actors, Arenas and Aspirations, Knowledge Societies in History, Routledge, London, pp. 208-224, doi: 10.4324/9781003019275.

Östh Gustafsson, H. (Forthcoming), "The humanities in crisis: comparative perspectives on a recurring motif", in Paul, H. (Ed.), Writing the History of the Humanities: Questions, Themes, and Approaches, Bloomsbury, London.

Östling, J. (2020), "Circulation, arenas, and the quest for public knowledge: historiographical currents and analytical frameworks", History and Theory, Vol. 59 No. 4, pp. 111-124, doi: 10.1111/ hith.12184.

Petrini, H. (1918), "Realskolans omläggning på naturvetenskaplig grund", Pedagogisk Tidskrift, Vol. 54, pp. 289-292.

Petrini, H. (1934), "Grunderna för ett rationellt ordnande av undervisningen på realgymnasiet", Pedagogisk Tidskrift, Vol. 70, pp. 45-64.

Plumb, J.H. (Ed.) (1964), Crisis in the Humanities, Penguin, Harmondsworth.

Rabe, G.R. (1865), "Om lärobokens betydelse med afseende på den offentliga elementarundervisningen”, Pedagogisk Tidskrift, Vol. 1, pp. 13-25.

Ribbner, B. (1967), "Diskussionen om latinets ställning vid 1800-talets mitt", Pedagogisk Tidskrift, Vol. 103, pp. 50-57.

R-m, P. (1903), "Läroverksreformen och de klassiska studierna”, Pedagogisk Tidskrift, Vol. 39, pp. 257-259.

Sahlin, C.Y., Bergstedt, H., Kastman, C., Schwartz, E., Flensburg, E.G. and Jacobsson, A. (1911), "Svenska humanistiska förbundets petition angående försök med en fullständig klassisk linje vid några allmänna läroverk”, Pedagogisk Tidskrift, Vol. 47, pp. 110-117.

Sainio, M.A. (1966), "Några synpunkter på historisk-pedagogisk forskning”, Pedagogisk Tidskrift, Vol. 102, pp. 120-123.

Samuelsson, J. (1907), “Omläggning af latinstudiet”, Pedagogisk Tidskrift, Vol. 43, pp. 23-32.

Sandy (1873), “Om realbildningen vid Sveriges elementarläroverk”, Pedagogisk Tidskrift, Vol. 10, pp. 1-15.

Schröder, E.A. (1828), "Öfver åtskilliga främmande länders undervisningsverk”, Svea, Vol. 11, pp. 221-409.

S.G.C (1870), “Gamla och nya pedagogiska åsigter”, Pedagogisk Tidskrift, Vol. 6, pp. 275-289.

Sillén, J. (1886), “Något om formel bildning”, Pedagogisk Tidskrift, Vol. 22, pp. 96-103. 
HER

51,2

Simon, Z.B. (2019), History in Times of Unprecedented Change: A Theory for the 21st Century, Bloomsbury, London.

Sjöstrand, W. (1954), Pedagogikens historia: från antiken till första världskriget, Gleerup, Lund, Vol. 1.

Sjöstrand, W. (1967), "Den historisk-pedagogiska forskningens raison d'être", Pedagogisk Tidskrift, Vol. 103, pp. 122-126.

Sjövall, B. (1939), "Historieundervisningens dilemma", Pedagogisk Tidskrift, Vol. 75, pp. 212-222.

Snow, C.P. (1959), The Two Cultures and the Scientific Revolution, Cambridge University Press, Cambridge.

Söderlund, A. (1958), "Översiktlig framställning av pedagogikens historia med hänsyn till vår tids skolproblem", Pedagogisk Tidskrift, Vol. 94, pp. 65-93.

Söderlund, A. (1961), "Regimskifte 1962”, Pedagogisk Tidskrift, Vol. 97, p. 182.

Solders, S. (1964), "Ord i Pedagogisk Tidskrift om klassiska studier”, Pedagogisk Tidskrift, Vol. 100, pp. 301-328.

Thavenius, J. (1981), Modersmål och fadersarv: svenskämnets traditioner $i$ historien och nuet, Symposion, Järfälla.

Thue, F.W. (2019), "Den historiske allmendannelse: historiefaget i høyere/videregående skole, 18692019”, Historisk Tidsskrift, Vol. 98 No. 2, pp. 167-190.

Tidner, E. (1944), “Den antika historien i läroverken”, Pedagogisk Tidskrift, Vol. 80, pp. 78-84.

Torius, K.J. (1933), "En historisk lärobok förr och nu”, Pedagogisk Tidskrift, Vol. 69, pp. 136-154.

Uhlig, G. (1897), "Det humanistiska gymnasiets uppgifter och utsikter”, Pedagogisk Tidskrift, Vol. 33, pp. 297-304.

Waldenström, P. (1866), “Strödda tankar i skolfrågor”, Pedagogisk Tidskrift, Vol. 2, pp. 113-146.

Wennås, O. (1966), Striden om latinväldet: idéer och intressen i svensk skolpolitik under 1800-talet, Almqvist \& Wiksell, Uppsala.

Wennerholm, S. (2008), "Gränsdragning och naturvetenskapens kunskapskulturer: exempel från svenska läroverk 1930-1970", in Widmalm, Sven (Ed.), Vetenskapens sociala strukturer: sju historiska fallstudier om konflikt, samverkan och makt, Nordic Academic Press, Lund, pp. 137-166.

Westberg, J. (2015), "Multiplying the origins of mass schooling: an analysis of the preconditions common to schooling and the school building process in Sweden, 1840-1900", History of Education, Vol. 44 No. 4, pp. 415-436, doi: 10.1080/0046760X.2015.1015625.

Westberg, J. (2017), "Vad är utbildningshistoria? Ett forskningsfälts historia, framtid och relation till pedagogikämnet”, Utbildning och Demokrati, Vol. 26 No. 3, pp. 7-37.

Wiberg, A. (1939), "Carl Ulric Broocmans projekterade realskola i Stockholm 1806", Pedagogisk Tidskrift, Vol. 75, pp. 5-19.

Wiberg, A. (1964), "Pedagogisk Tidskrifts uppkomst och utveckling 1865-1964", Pedagogisk Tidskrift, Vol. 100, pp. 141-226.

Zachrisson, R.E. (1916), "Några synpunkter rörande frågan om gymnasiets omorganisation", Pedagogisk Tidskrift, Vol. 52, pp. 305-314.

\section{About the authors}

Isak Hammar, $\mathrm{PhD}$, is associate professor at the Department of History, Stockholm University. His research focuses on the history of humanities, and particularly on the relationship between the humanities and the natural sciences during the first half of the 19th century. Recent publications include "Classical Nature: Natural History, Classical Humanism and the Value of Knowledge in Sweden, 18001850 " in Journal for the History of Knowledge. Together with Johan Östling, he is the editor of the Forum section "The Circulation of Knowledge and the History of Humanities" for History of humanities. Isak Hammar is the corresponding author and can be contacted at: isak.hammar@historia.su.se 
Hampus Östh Gustafsson, $\mathrm{PhD}$, is a postdoctoral researcher at the Department of History of Science and Ideas, Uppsala University. In 2021, he defended his doctoral thesis on the legitimacy of the humanities in Swedish politics of knowledge 1935-1980. He is also the editor of a forthcoming volume with Amsterdam University Press on the modern history of the Swedish humanities. Recent publications include "Mobilising the Outsider: Crises and Histories of the Humanities in the 1970s Scandinavian Welfare-States" in Johan Östling, Niklas Olsen and David Larsson Heidenblad (eds.), Histories of Knowledge in Postwar Scandinavia. Actors, Arenas and Aspirations (Routledge, 2020). 